\title{
Heritage Valuation Driving Sustainability of Cultural Capital in Bishnupur in Eastern India
} Asmita BASU, Anupam DE

\begin{abstract}
Cultural heritage of a country represents an array of monuments, historic buildings, arts and crafts, indigenous skills and traditions. The emerging threats to the cultural resources by way of decay, loss or destruction, has become a prime concern today. Heritage has become one of the vital components of tourism industry. It is being considered as cultural capital. The process of valuation of this capital is very complex since Heritage is basically a nonmarketed good. Different techniques used for valuating environmental resources which are similar in nature to Heritage, have led to the development of economic valuation models especially for valuation of Heritage as cultural assets. This economic approach has helped to derive the real value of heritage sites by way of consumer's surplus and consumer's willingness to pay for the use of cultural heritage assets and sustain sites for future generations.
\end{abstract}

Key words: Heritage, Economic valuation, Travel Cost Model, Sustainability.

\section{Heritage as a Cultural Asset}

A country bears the symbols of its prolific cultural heritage in the form of heritage monuments, historic places, arts and crafts and traditional skills. In general, capital is defined as assets which in combination with other inputs particularly labour transform into other goods, which are then used to generate revenue. The concept of capital has been prevalent in economics since the very beginning. This definition of capital has gradually included the concepts of Human capital and Natural capital. Further extending the concept of capital, the idea of cultural capital has been formulated. It has been observed that both tangible and intangible Heritage has all the characteristics of cultural assets, so it can be regarded as cultural capital ${ }^{1}$.

Heritage is in fact regarded as one of the most valuable and fastest growing components of tourism. Conservation of heritage sites is considered to be a vital component of their management since they are irreplaceable resources for the tourism industry. It is noteworthy that cultural resources possess high social values, serve as captivating factor for the visitors as well as stimulate sustainable development across the planet ${ }^{2}$.

1 David Throsby. “Cultural capital.” Journal of cultural economics 23, no. 1 (1999): 3-12.

2 Vinita Deodhar. "Does the Housing Market Value Heritage? Some Empirical Evidence”. No. 0403 (Research Paper: Macquarie University, 2004). 
In the process of urban planning and management, the issues pertaining to conservation of heritage sites have been mostly ignored by the planners. Due to this fact, the heritage sites and monuments have been put through decay and destruction and eventually led to the loss of cultural capital. Owing to the threats of permanently losing the cultural heritage of the nations, urban planners are now more concerned about preservation and conservation of tangible and intangible heritage ${ }^{3}$.

Heritage can be treated as a non-marketed good. Since heritage is being treated as an alternate form of capital, it is important to understand its possible contributions to economic output leading to the growth of the economy. The greatest challenge of economic valuation of cultural heritage lies in the methods to be applied. In general, valuation techniques are mostly implemented for environmental resources. During recent periods, much research concerning cultural capital and assets has been conducted which has revealed the similarity with the environmental resources, particularly since these do not have proper market to evaluate their economic prices either. It has also been discerned that the cultural heritage assets belong to the category of public goods ${ }^{4}$. Therefore, appropriate valuation techniques should be applied to evaluate the heritage sites and understand the demand for the sites among the various stakeholders such as the residents, tourists and others.

\section{Valuation of Heritage}

Different researches have suggested a number of methods to evaluate heritage sites economically, considering them as cultural assets. Many scholars have tried to focus on how to deal with the valuation of the cultural heritage in the form of cultural assets of a particular community, region or the nation as a whole. The valuation techniques which are applied for environmental resources have been modified and used for economic valuation of non-marketed goods such as cultural heritage assets. One such type of non-marketed valuation techniques is known as Travel Cost Method (TCM). According to this model, a visitor is considered to choose one or more heritage sites depending on site qualities while the rate of visit to the site is based mainly on the relative travel costs from home to the respective heritage site $^{5}$.

3 Mousumi Dutta, Sarmila Banerjee, and Zakir Husain. "Untapped demand for heritage: A contingent valuation study of Prinsep Ghat, Calcutta.” Tourism Management 28, no. 1 (2007): 83-95.

4 Andrea Báez-Montenegro, Ana María Bedate, Luis César Herrero, and Jose Ángel Sanz. "Inhabitants' willingness to pay for cultural heritage: a case study in Valdivia, Chile, using contingent valuation." Journal of Applied Economic 15, no. 2 (2012): 235-258.

5 Sukanya Das. "Travel cost method for environmental valuation." (Dissemination Paper 23, Center of Excellence in Environmental Economics, Madras School of Economics, 2013). 
Harold Hotelling gave the first notion under the Travel Cost Method (TCM), where he suggested that a model for evaluating the re-creation value of a site could be developed based on the visitors' expenditures for visiting the site ${ }^{6}$. The initial model was further developed by Clawson $(1959)^{7}$ and Clawson and Knetsch $(1966)^{8}$. TCM is a questionnaire method used to conduct survey involving samples of visitors to the sites to determine their location, the necessary demographic and attitudinal data, number of visits to the site and other sites being considered, and information about the trip, such as purpose, length and costs. From these statistics, the cost of visits may be estimated and linked to the frequency of visits and other important characteristics to construct a connection of demand. In the most elementary scenario, this demand function may be used to determine the recreational value of the entire site, while more complex research can seek to build demand equations for particular recreation site's features and values evaluated for these unique elements.

\section{Heritage sites of Bishnupur}

Bishunupur, the historical capital of the Malla Dynasty (16 ${ }^{\text {th }}$ century A.D.), is a small temple town in Bankura District of West Bengal. Tourists mainly visit this place for weekend getaways from the hustle and bustle of the city. This small town is surrounded by a number of heritage monuments. Historians believe that there were around thousands of religious places in Bishnupur and its adjoining areas. The majority of the heritage monuments are protected neither by the state nor by the central authorities. They are maintained by private bodies. The Archaeological Survey of India (ASI) has protected the three major historic heritage sites in Bishnupur namely the Rasa-mancha, Shyam Rai temple and the Jor Bangla temple. The cultural, social, architectural and historic values of the heritage sites of Bishnupur make them worthy of being designated as World Heritage Sites, however they are now on the tentative list of World Heritage Sites?.

${ }^{6}$ Harold Hotelling. "The Economics of Public Recreation: The Prewitt Report." National Parks Service (Washington D.C.: 1947).

7 Marion Clawson. Methods of Measuring the Demand for and Value of Outdoor Recreation, Reprint, no. 10 (Washington D.C: Resources for the Future Inc, 1959).

8 Marion Clawson, and Jack L. Knetsch. Economics of outdoor recreation (Washington D.C.: RFF Press, 2011).

9 Basu, Asmita. "Contexts and Concerns for Sustainability of Cultural Heritage Sites of Bishnupur.” PLURAL. History, Culture, Society VII, no.1 (2020): 120-130. 


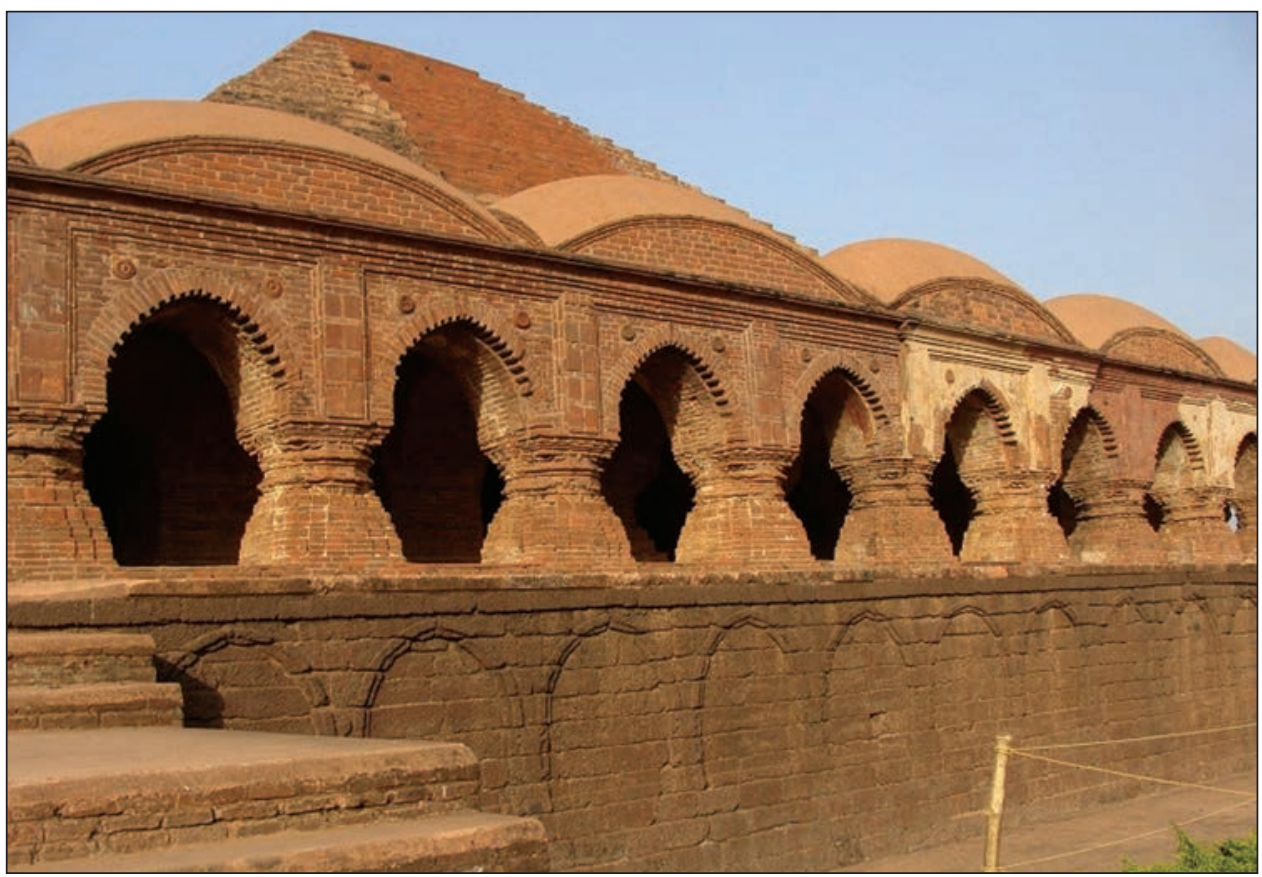

Fig. 1. Rasa-mancha

Rasa-mancha: the Rasa-mancha (Fig.1) depicts a stage or a mancha which was constructed by King Bir Hambir in AD $1600^{10}$. This monumental structure was built for the purpose of carrying out rituals and festival celebration particularly during the Rasa festival. Tourists have shown keen interest in visiting this heritage site for its aesthetic value, unique architectural construction with arched galleries, pyramidal elevation, domed roof circumscribing a small shrine area located in the centre of the structure ${ }^{11}$.

Shyam Rai temple: another heritage gem visited commonly by the tourists is the Shyam Rai temple (Fig.2). This magnificent temple is mostly distinguished by its Pancha-ratna or the five towers. Intricate terracotta panels depicting scenes from mythological stories of Ramayana and Krishnalila, adorn the main façade. Historical records affirm that this structural marvel was constructed by King Raghunatha Singha in the year $1643^{12}$.

${ }^{10}$ Sachindra S Biswas. Bishnupur, (Director General, Archaeological Survey of India: Delhi, 1992): 10 .

${ }^{11}$ Sujay Kumar Mandal, Tanaya Mukherjee, and Bidhan Mondal. “The Traditional Terracotta Temple Architecture of the Temple Town Bishnupur: A Study on Structure, Style, Themes and Motifs of Ornamentation." International Journal of Liberal Arts and Social Science 4, no. 1 (2016): 13.

12 Biswas. Bishnupur..., 20-24. 
Jor Bangla Temple: this twin hut styled temple (Fig3) is a part of the Bishnupur group of temples (as regarded by ASI) which creates a unique attraction for the tourists. Its walls are beautifully ornated with terracotta plaques. It is regarded to be one of the best carved temples which make the historic heritage of Bishnupur prominent in front of all ${ }^{13}$. The Jor Bangla temple was erected by the Malla rulers in AD 1734-35 representing a distinct Bengal style of architecture ${ }^{14}$.

\section{The theoretical development of Travel Cost Model}

The general model gauges the recreational value generated for a specific site by establishing a relationship between the demand for that site (estimated through number of visits to the site) and price (estimated through the costs incurred for a visit). A simple TCM model can be defined by a ,trip-generation function' (tgf) such as;

$$
V=f(C, X)
$$

where, $\mathrm{V}=$ Number of visits to a site

$\mathrm{C}=$ Visit costs (mainly the travel cost)

$\mathrm{X}=$ Additional socio-economic factors accounting for the variance of $\mathrm{V}^{15}$.

The Travel Cost Model has two categories - namely the Individual Travel Cost Method and the Zonal Travel Cost Method based on the dependent variable which in this case is $V$. Individual Travel Cost Method, one of the variants of TCM elucidate the definition of dependent variable as individual frequency of the visit to the site during a specified period. The other variant, Zonal Travel Cost Method (ZTCM) at the outset segregates the entire region into zones demarcated by the visitors' origin and then considers the visit rate as the dependent variable. The visit rate is defined as the frequency of zonal visits during a specified period divided by the total population of the identified zone.

The trip generating function can therefore be modified as per the ZTCM technique:

$$
V_{z s} / N_{z}=f\left(C_{z}, X_{z}\right)
$$

where, $\mathrm{V}_{z s}=$ Visits from zone $\mathrm{z}$ to site $\mathrm{s}$

$\mathrm{N}_{z}=$ Population of zone $\mathrm{z}$

\footnotetext{
13 “Bankura," Monuments, ASI Kolkata Circle, http://www.asikolkata.in/bankura.aspx (accessed: 10.04.2021).

${ }^{14}$ Biswas. Bishnupur..., 15.

${ }^{15}$ Das. "Travel cost method...".
} 
$\mathrm{C}_{z}=$ Visit costs from zone $\mathrm{z}$ to site $\mathrm{s}$

$\mathrm{X}_{z}=$ Socioeconomic explanatory variables in zone $\mathrm{z}$

The visitor rate, $V_{z s} / N_{z}$, is often calculated as visits per 1,000 population in zone $\mathrm{z}$.

\section{Application of Zonal Travel Cost Method for Valuation of Bishnupur Heritage Sites}

In the present study, the Zonal Travel Cost Method (ZTCM) is applied to the heritage sites of Bishnupur. The first step of the Zonal Travel Cost Method consisted of a survey in order to understand the visit rate in Bishnupur and to identify the zones from which the visitors had travelled frequently as well. A convenience sampling method was used to collect a sample of 310 respondents out of which 300 relevant responses were obtained. It was observed that the geographical locations of the respondents pointed out nine major districts from where the visitors had travelled to see the heritage sites of Bishnupur. In this method, identification of the zones plays an important role. The nine districts (Listed in Table 1) have been thus considered as the nine distinct zones for the purpose of applying the ZTC method.

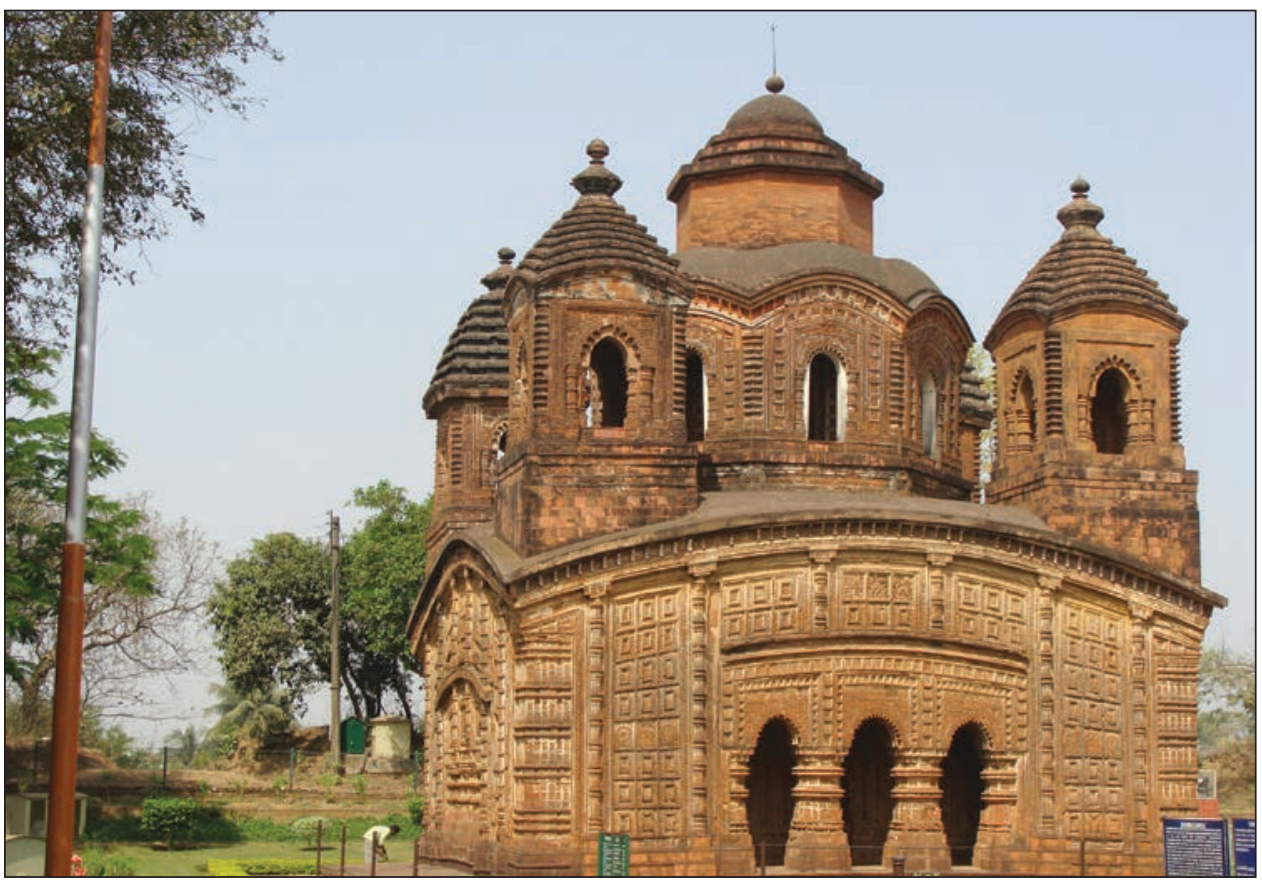

Fig 2. Shyamrai Temple 
Visit Rate Calculation:

The data collected through the survey was used to calculate the Visit Rate. This rate was calculated in relation to the number of inhabitants of the districts (data obtained from Census 2011) from where the tourists had visited Bishnupur firstly. The visit rate per capita was calculated and then the visit rate per 10,000 inhabitants was calculated to standardize the rate as shown in Table 1.

Table 1. Visit Rate Calculation

\begin{tabular}{|l|c|c|c|c|}
\hline \multicolumn{1}{|c|}{ Location } & $\begin{array}{c}\text { Population (as } \\
\text { per Census } \\
\text { 2011) }\end{array}$ & $\begin{array}{c}\text { Number of } \\
\text { visitors }\end{array}$ & $\begin{array}{c}\text { Visit rate per } \\
\text { capita }\end{array}$ & $\begin{array}{c}\text { Visit rate } \\
\text { per 10,000 } \\
\text { inhabitants } \\
\text { (Y range) }\end{array}$ \\
\hline Bankura & $1,37,386$ & 120 & 0.000873 & 8.734514 \\
\hline Midnapore & $1,69,264$ & 20 & 0.000118 & 1.181586 \\
\hline Bardhaman & $3,14,265$ & 15 & 0.000048 & 0.477304 \\
\hline Howrah & $10,77,075$ & 10 & 0.000009 & 0.092844 \\
\hline $\begin{array}{l}\text { North 24 Parganas } \\
\text { (Dumdum) }\end{array}$ & $1,15,000$ & 5 & 0.000043 & 0.434783 \\
\hline Kolkata & $1,40,35,959$ & 105 & 0.000007 & 0.074808 \\
\hline Hooghly (Haripal) & $2,61,073$ & 10 & 0.000038 & 0.383035 \\
\hline Haldia & $20,01,000$ & 5 & 0.000002 & 0.024988 \\
\hline $\begin{array}{l}\text { South 24 Parganas } \\
\text { (Rajpur-Sonarpur) }\end{array}$ & 424368 & 5 & 0.000012 & 0.117822 \\
\hline Coochbehar & 77,935 & 5 & 0.000064 & 0.641560 \\
\hline
\end{tabular}

Zonal Travel Cost Calculation:

The second step focuses on calculating the travel cost from these nine zones with the help of Zonal Travel Cost Method (ZTCM). The Zonal Travel Cost Method, as suggested by Bedate, ${ }^{16}$ is as follows:

$$
\text { Cost of travel }=\frac{\text { Distance in } \mathrm{km} \times 2 \times 24}{(\text { Number of vehicle occupants }) \times(\text { length of trip in days })}
$$

From the survey it was evident that most of the tourists travelled by land since they were the residents of the neighbouring districts. In order to calculate the cost of travel, it was important to identify the distance travelled by land. The cost per kilometer was Rs. 24, since this is the amount of travel allowance

\footnotetext{
${ }^{16}$ Ana Bedate, Luis César Herrero, and José Ángel Sanz. "Economic valuation of the cultural heritage: application to four case studies in Spain." Journal of cultural heritage 5, no. 1 (2004): 101-111.
} 
given by7CPC of Govt. of India. This figure includes fuel costs, vehicle maintenance and depreciation, insurance, taxes, and other expenses. As opined by Bedate, to calculate the cost of travel, the formula should take into consideration the round-trip cost, the duration of the trip and, whether the trip is made in a personal vehicle, and the number of vehicle occupants as well. Along with the above-mentioned information regarding travel cost, the entry fee per person to the heritage sites were also considered. The entry fee to the three heritage sites in Bishnupur, namely-Shyamrai temple, Jor Bangla temple and Rasamancha is administered by ASI.

Table 2. Calculation of Zonal Travel Cost

\begin{tabular}{|l|c|c|c|c|}
\hline Location & $\begin{array}{c}\text { Distance from } \\
\text { Bishnupur (Kms) }\end{array}$ & $\begin{array}{c}\text { Length of trip } \\
\text { (in days) }\end{array}$ & $\begin{array}{c}\text { No. of vehicle } \\
\text { occupants }\end{array}$ & $\begin{array}{c}\text { Cost of travel per } \\
\text { person + entry } \\
\text { fee** (Rs.) }\end{array}$ \\
\hline Bankura & 38 & 1 & 24 & 96 \\
\hline Mednipore & 75 & 1 & 10 & 380 \\
\hline Bardhaman & 82 & 2 & 4 & 512 \\
\hline Howrah & 134 & 2 & 4 & 824 \\
\hline N24 Prg & 135 & 2 & 4 & 830 \\
\hline Kolkata & 140 & 2 & 4 & 860 \\
\hline Hooghly & 168 & 2 & 4 & 1028 \\
\hline Haldia & 192 & 2 & 4 & 1172 \\
\hline S24 Prg & 200 & 2 & 4 & 1220 \\
\hline
\end{tabular}

*During the survey, the $9^{\text {th }}$ district, from where very few tourists had come, was Coochbehar. Since this district is $673 \mathrm{~km}$ away from Bishnupur, tourists did not prefer bus or car for the purpose of travel. So, this district has been considered as an outlier data point and has not been considered during the analysis.

** Entry fee for Indian tourists is Rs. 20 (by ASI).

The data obtained from Table 1 was further analyzed with the help of statistical tool. Firstly, the correlation coefficient was obtained, in order to understand whether there is any correlation between the obtained variables.

Table 3. Correlation Matrix

\begin{tabular}{|c|c|c|}
\hline & Visit rate & $\begin{array}{c}\text { Travel } \\
\text { cost }\end{array}$ \\
\hline Visit rate & 1 & \\
\hline Travel cost & -0.7408 & 1 \\
\hline
\end{tabular}

The Correlation matrix in table indicates that the correlation coefficient is -0.74. It means that the Visit rate and travel cost are negatively correlated. 
Further, the data were analyzed with the help of SPSS software which resulted in $\mathrm{R}^{2}=0.552$ and Adjusted $\mathrm{R}^{2}=0.488$ (Table 4). This indicates that the linear regression explains $55.2 \%$ of the variance in the data.

Table 4. Model Summary in SPSS

\begin{tabular}{|c|c|c|c|c|}
\hline \multicolumn{5}{|c|}{ Model Summary } \\
\hline Model & $\mathrm{R}$ & $\mathrm{R}$ Square & $\begin{array}{c}\text { Adjusted R } \\
\text { Square }\end{array}$ & $\begin{array}{c}\text { Std. Error of the } \\
\text { Estimate }\end{array}$ \\
\hline 1 & $.743^{\mathrm{a}}$ & .552 & .488 & 2.0168449 \\
\hline \multicolumn{7}{|l}{ a. Predictors: (Constant), Travel cost } \\
\hline
\end{tabular}

Further, Table 5 establishes the Regression coefficients. The ANOVA table (Table 6) is constructed which shows values for F-test. In the case of linear regression, F-test assumes the null hypothesis that there is no linear relationship between the two variables (which is denoted by $\mathrm{R}^{2}=0$ ). From the present analysis, it is observed that $\mathrm{F}=8.618$ with 8 degrees of freedom. From the SPSS ANOVA table $\mathrm{p}$ value $=0.022$, as we can see, $\mathrm{p}<0.05$ and hence, it is significant.

Table 5. Regression Analysis in SPSS

\begin{tabular}{|c|c|c|c|c|c|c|c|c|}
\hline \multicolumn{9}{|c|}{ Coefficients } \\
\hline & \multirow[t]{2}{*}{ Model } & \multicolumn{2}{|c|}{$\begin{array}{l}\text { Unstandardized } \\
\text { Coefficients }\end{array}$} & \multirow{2}{*}{\begin{tabular}{|c}
$\begin{array}{c}\text { Standardized } \\
\text { Coefficients }\end{array}$ \\
Beta
\end{tabular}} & \multirow[t]{2}{*}{$\mathrm{t}$} & \multirow[t]{2}{*}{ Sig. } & \multicolumn{2}{|c|}{$\begin{array}{c}95.0 \% \\
\text { Confidence } \\
\text { Interval for B }\end{array}$} \\
\hline & & B & $\begin{array}{l}\text { Std. } \\
\text { Error }\end{array}$ & & & & $\begin{array}{l}\text { Lower } \\
\text { Bound }\end{array}$ & $\begin{array}{l}\text { Upper } \\
\text { Bound }\end{array}$ \\
\hline \multirow{2}{*}{1} & (Constant) & 5.587 & 1.614 & & 3.462 & .011 & 1.771 & 9.402 \\
\hline & Travel cost & -.006 & .002 & -.743 & -2.936 & .022 & -.010 & -.001 \\
\hline
\end{tabular}

Table 6. ANOVA in SPSS

\begin{tabular}{|l|c|c|c|c|c|c|}
\hline \multicolumn{7}{|c|}{ ANOVA } \\
\hline \multicolumn{2}{|c|}{ Model } & $\begin{array}{c}\text { Sum of } \\
\text { Squares }\end{array}$ & $\mathrm{df}$ & Mean Square & $\mathrm{F}$ & Sig. \\
\hline \multirow{2}{*}{1} & Regression & 35.057 & 1 & 35.057 & 8.618 & $.022^{\mathrm{b}}$ \\
\cline { 2 - 7 } & Residual & 28.474 & 7 & 4.068 & & \\
\cline { 2 - 7 } & Total & 63.530 & 8 & & & \\
\hline \multicolumn{2}{|l}{ a. Dependent Variable: Visit rate per 10,000 inhabitants } \\
\multicolumn{2}{|l}{ b. Predictors: (Constant), Travel cost } \\
\hline
\end{tabular}




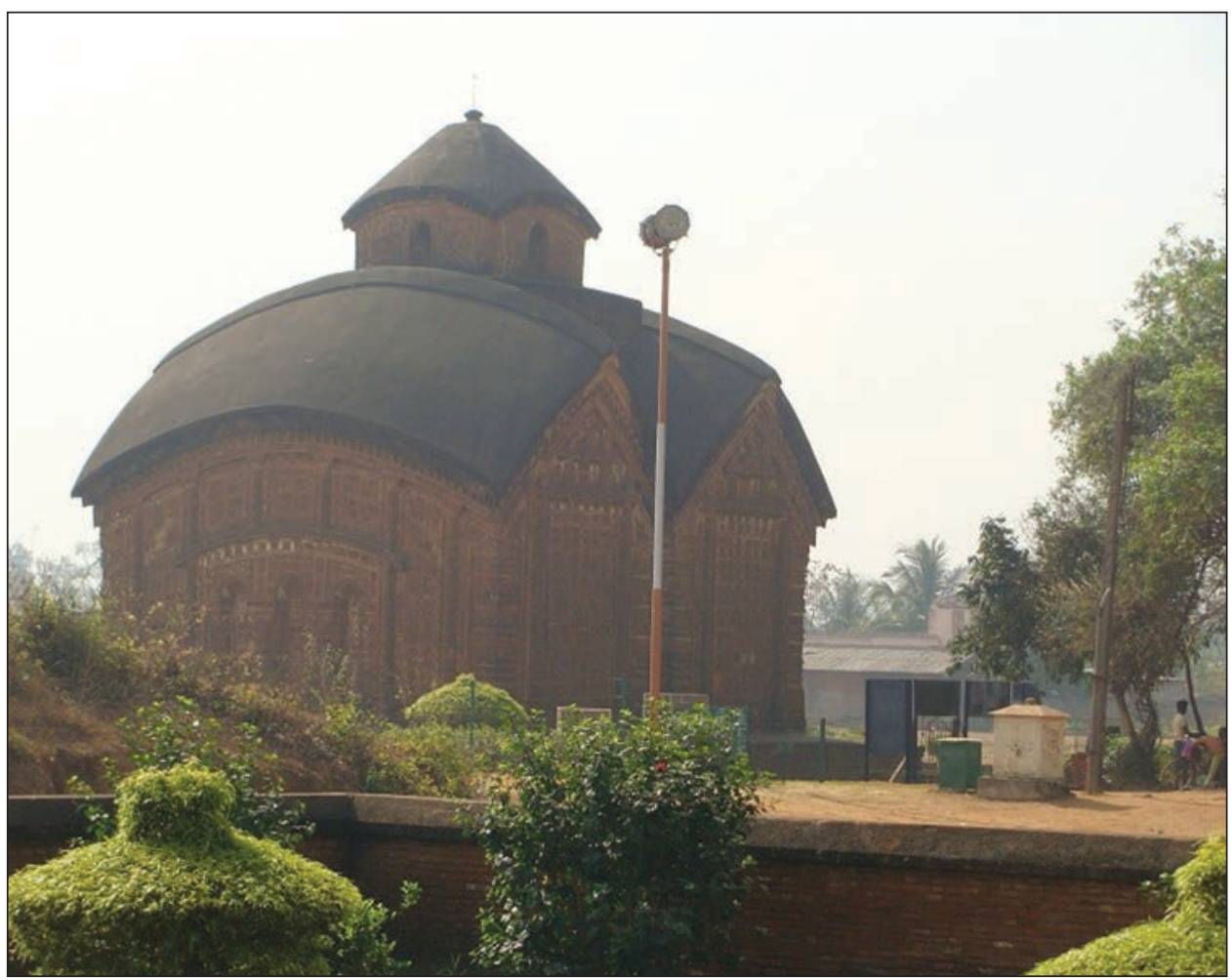

Fig. 3. Jor Bangla Temple

Thus, a liner relationship is established between the Visit rate and the Travel cost incurred to visit the heritage sites, from the various analytical studies. It is essential to understand this factor, since on the basis of this relationship, the demand function can be established. The demand function can be expressed through the equation $\mathbf{y}=\mathbf{5 . 5 8 6 6 - 0 . 0 0 5 6 x}$. It implies that an additional 5.5866 travel cost would decrease the visit rate to the heritage site by $\mathbf{0 . 0 0 5 6}$. The travel cost may therefore be treated as important factor to understand the demand for the heritage sites in Bishnupur. This factor would also help us in establishing the consumer's willingness to pay and consumer surplus in the next phase of the study.

\section{Analysis and Observations}

The present study analyses how the demand for the heritage site would be changing with respect to the travel cost. We have seen that the entry fee for the three sites, as imposed by ASI, is very low. So, the majority of the rev- 
enue generated from the entry fee is utilised for the basic maintenance purpose of the sites. In order to bring in sustainability of these heritage sites, to develop site museums, light and sound programmes, awareness campaigns and various similar programmes and infrastructures, a regular source of funds would be required. The ZTC Model used in this study comes into play at this point. This model can be utilitarian in forecasting the additional revenue generation by estimating the consumer's surplus and consumer's willingness to pay.

\section{Determination of Consumer's Surplus:}

The demand equation $\mathbf{y}=\mathbf{5 . 5 8 6 6 - 0 . 0 0 5 6} x$ can be used to identify the consumer surplus by estimating the number of visits on the basis of the additional cost that the visitors would be willing to pay to visit the heritage sites of Bishnupur apart from the Travel cost calculated earlier (Table 2). At the calculated travel cost, the total no of visits from different zones was 295. On the basis of the demand equation formed from the previous data, a final demand curve can be established through linear interpolation on the line constructed by the points forming the basic demand curve, which depicts the variation in the total number of visits as the travel cost increases. It was observed that the number of visits decreased on increasing the additional travel cost beyond Rs. 150 . The variation in the number of visits with the increase of additional cost has been graphically represented through the demand curve for the heritage sites of Bishnupur in Fig. 4.

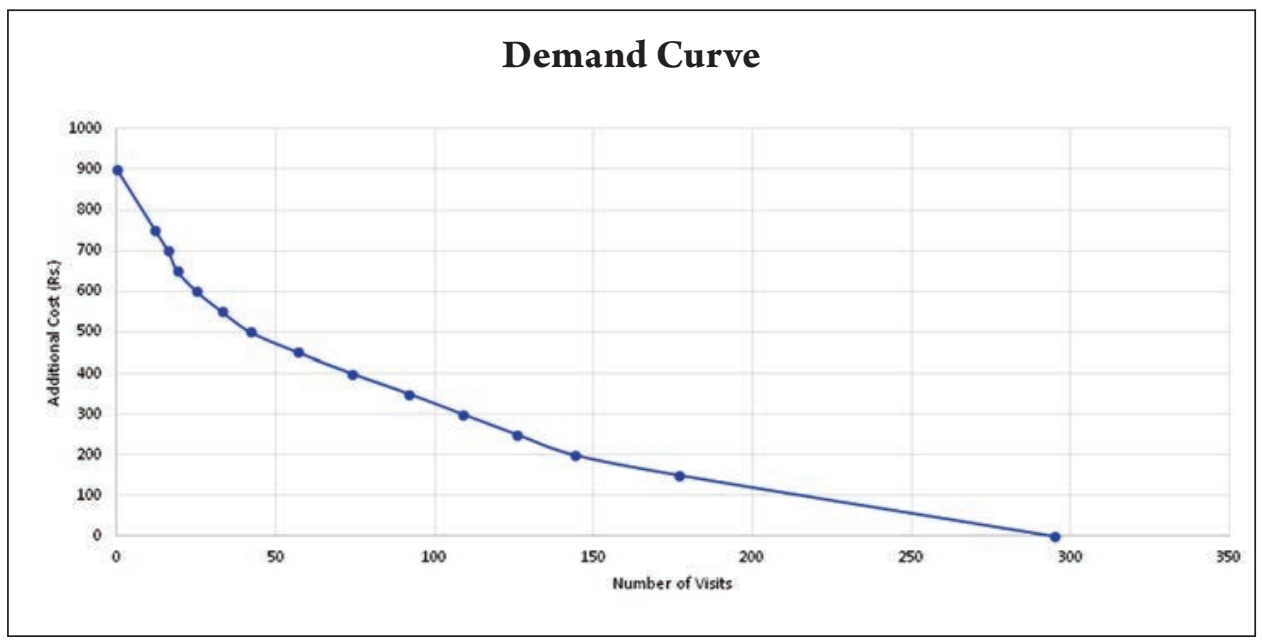

Figure 4. Demand curve for Heritage sites of Bishnupur 
Thus, the area under the curve (Fig.4) gives the total consumer surplus for all the nine zones. So, after calculating the area under the curve we observe that consumer surplus equals Rs.78,050. Thus, the consumer's willingness to pay can be inferred to be Rs. 265 per person, since the number of visitors surveyed for this study was 295 .

The data obtained from Archaeological Survey of India (ASI), mention that the number of Indian and foreign visitors was 1,55,521 for the year 2019-20. Therefore, the total annual consumer surplus can be estimated by using this model. This serves as the regular source of funds which could be used to sustain the heritage sites as well as induce socio-economic growth of the region.

\section{Conclusion}

The real challenge lies in the economic valuation of cultural capital due to the non- existence of markets to reflect the real value of the heritages in terms of economic prices. It is observed that the problem of valuation persists even though the visitors express a willingness to pay for the heritage which has a societal value along with signs of cultural identity. Thus, it is really important that alternate methods are applied to realize the preferences of significant stakeholders of cultural capital through methods like that of the Travel Cost Model. The relevance of this method lies in estimating the visitor's willingness to pay for the consumption of the cultural heritage assets which is measured in terms of economic pursuits associated with travelling to the heritage sites. This study also entails various policy and decision-making processes regarding the economic sustainability of the heritage sites. If applied to rich cultural heritage sites, the Zonal Travel Cost Model can forecast the amount of surplus funds that can be generated through consumer's surplus. This economic approach will also be beneficial for all the policy makers and future investors and, in its turn, it will lead to the overall economic development and sustainability of the heritage sites and their adjoining areas.

\section{Rezumat}

Patrimoniul cultural al unei țări este reprezentat de o serie de monumente, clădiri istorice, creații artistice, meșteşuguri, abilități şi tradiții indigene. Amenințările curente asupra resurselor culturale prin deteriorare, pierdere sau distrugere, au devenit astăzi o preocupare principală. Patrimoniul a devenit una dintre componentele vitale ale industriei turismului. Procesul de evaluare a acestui capital cultural este foarte complex deoarece patrimoniul este în esență un bun necomercializat. Diferitele tehnici utilizate pentru evaluarea resurselor de mediu, care sunt similare cu cele de patrimoniu, au 
condus la dezvoltarea de modele de evaluare economică, în special pentru evaluarea bunurilor culturale. Această abordare economică a contribuit la obținerea valorii reale a moștenirii prin surplusul consumatorului și disponibilitatea consumatorilor de a plăti pentru utilizarea bunurilor de patrimoniu cultural și de a susține siturile pentru generațiile viitoare.

Cuvinte cheie: moștenire valoarea economică, model de costuri, sustenabilitate

Asmita Basu, Department of Management Studies, NIT Durgapur; AIM Kolkata, e-mail: asmita.basu2011@gmail.com

Anupam De, Department of Management Studies, NIT Durgapur, e-mail: anupam.de@dms.nitdgp.ac.in 